Notes and Comments

\title{
Survey of leaf-cutting ant species in the central region of the state of Tocantins, Brazil
}

\author{
Levantamento de espécies de formigas-cortadeiras na região central do estado do \\ Tocantins, Brasil
}

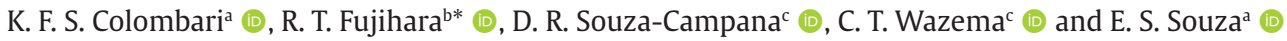 \\ aniversidade Estadual do Tocantins - Unitins, Palmas, TO, Brasil \\ bUniversidade Federal de São Carlos - UFSCar, Centro de Ciências Agrárias, Departamento de Ciências da Natureza, Matemática e Educação, \\ Araras, SP, Brasil \\ cUniversidade de Mogi das Cruzes - UMC, Núcleo de Ciências Ambientais, Mogi das Cruzes, São Paulo, Brasil
}

Ants (Hymenoptera, Formicidae) are eusocial insects classified into 17 extant subfamilies, 39 extant tribes, and about 17,000 extant species (AntWeb, 2021). They play key roles in different habitats, such as urban and rural areas (Mbenoun Masse et al., 2017; Souza-Campana et al., 2020), forests (Wilkie et al., 2010), and caves (Dáttilo et al., 2012), interacting with many organisms (Sebastiani et al., 2017), acting as ecosystem engineers (Toro et al., 2012; Martins et al., 2020), and, due to their high diversity and abundance, as reliable biological indicators (Choe, 2012; Santos-Silva et al., 2016).

The tribe Attini comprises 48 extant genera and 2,688 extant species (Bolton, 2021), and among them, Atta Fabricius, 1804, Acromyrmex Mayr, 1865, and Amoimyrmex Cristiano et al., 2020 - popularly named leaf-cutting ants - are important pests of forest plantations, agriculture, and livestock in several regions of Brazil and America (Britto et al., 2016). They represent together 53 species and 26 subspecies, being 17 species and one subspecies of genus Atta, 33 species and 22 subspecies of genus Acromyrmex, and three species of genus Amoimyrmex (Bolton, 2021).

The ant fauna of some Brazilian states, as Tocantins, has remained relatively understudied compared to other Brazilian states of similar size (Prado et al., 2019; Arruda et al., 2020; Jory and Feitosa, 2020), as well as the species of leaf-cutting ants (see, e.g., Dáttilo et al., 2010; Jaime, 2010; Guénard et al., 2017). The distribution data of leaf-cutting ants in Brazil is dispersed and the taxonomy is not updated (Delabie et al., 2011), and a regional list is an important tool for a better understanding of this distribution (Vicente et al., 2018; Arruda et al., 2020). Here, we present a survey of the species of leaf-cutting ants in the central region of the state of Tocantins, Brazil.

The survey was carried out in the Metropolitan Region of Palmas (capital of Tocantins), which corresponds to 16 municipalities according to the FNEM (2019) classification (Figures 1 and 2; Supplementary Material). We selected one hundred collection sites close to the main roads, distributed throughout the whole central region of the state. At each collection site, in a $500 \mathrm{~m}$ long by $50 \mathrm{~m}$ wide strip, marked at random, at least five exemplars of the ants (soldiers or foragers) found on the nests or on the foraging trails were collected (Forti et al., 2020). The collections were carried out from September 2019 to January 2020 (fortnightly) in two periods: from 5:00 am to $10: 00 \mathrm{am}$, and 2:00 pm to 7:00 pm.

The leaf-cutting ants were identified following taxonomic key from Fowler et al. (1993), and comparing specimens with the myrmecological collection of the Laboratório de Mirmecologia do Alto Tietê - LAMAT/ Universidade de Mogi das Cruzes, São Paulo, Brazil; the voucher specimens were deposited at the same collection. The species were named according to AntWeb (2021) and Bolton (2021).

Seven species and morphospecies of leaf-cutting ants were recorded in the central region of the state of Tocantins, Brazil (Figures 1 and 2; Supplementary Material): Acromyrmex coronatus (Fabricius, 1804), Acromyrmex heyeri (Forel, 1899), Atta laevigata (Smith, 1858), Acromyrmex rugosus (Smith, 1858), Atta sexdens (Linnaeus, 1758), Acromyrmex aff. balzani (Emery, 1890), Acromyrmex aff. landolti (Forel, 1885).

We observed that there was no predominance of species, which were spatially distributed in the Metropolitan Region of Palmas. The presence of A. laevigata is previously known in Porto Nacional, in the central region of the state of Tocantins (see Bragança and Medeiros, 2006), and A. sexdens was already recorded in Gurupi, in the south region of the state of Tocantins (see Silva and Souza, 2014; Dornelas et al., 2016). The occurrence of both species was already expected in our study because they have a wide distribution across Brazil (Forti and Boaretto, 1997).

The occurrence of Ac. balzani is also known in the south region of the state of Tocantins, in the municipality of Talismã (see Jaime, 2010); however, we present the first record of Ac. coronatus, Ac. heyeri and Ac. rugosus in the

*e-mail: rtfujihara@ufscar.br

Received: February 14, 2021 - Accepted: April 6, 2021 
state of Tocantins, as well as a potential new record of Ac. aff. landolti. These last four Acromyrmex species have been recorded in neighboring states, where Ac. coronatus had records in Bahia, Goiás, Mato Grosso, and Pará, and
Ac. heyeri had the closest record in Piauí. Acromyrmex landolti and Ac. rugosus had records in Bahia, Goiás, Mato Grosso, Maranhão, and Piauí (Guénard et al., 2017; Jory and Feitosa, 2020).

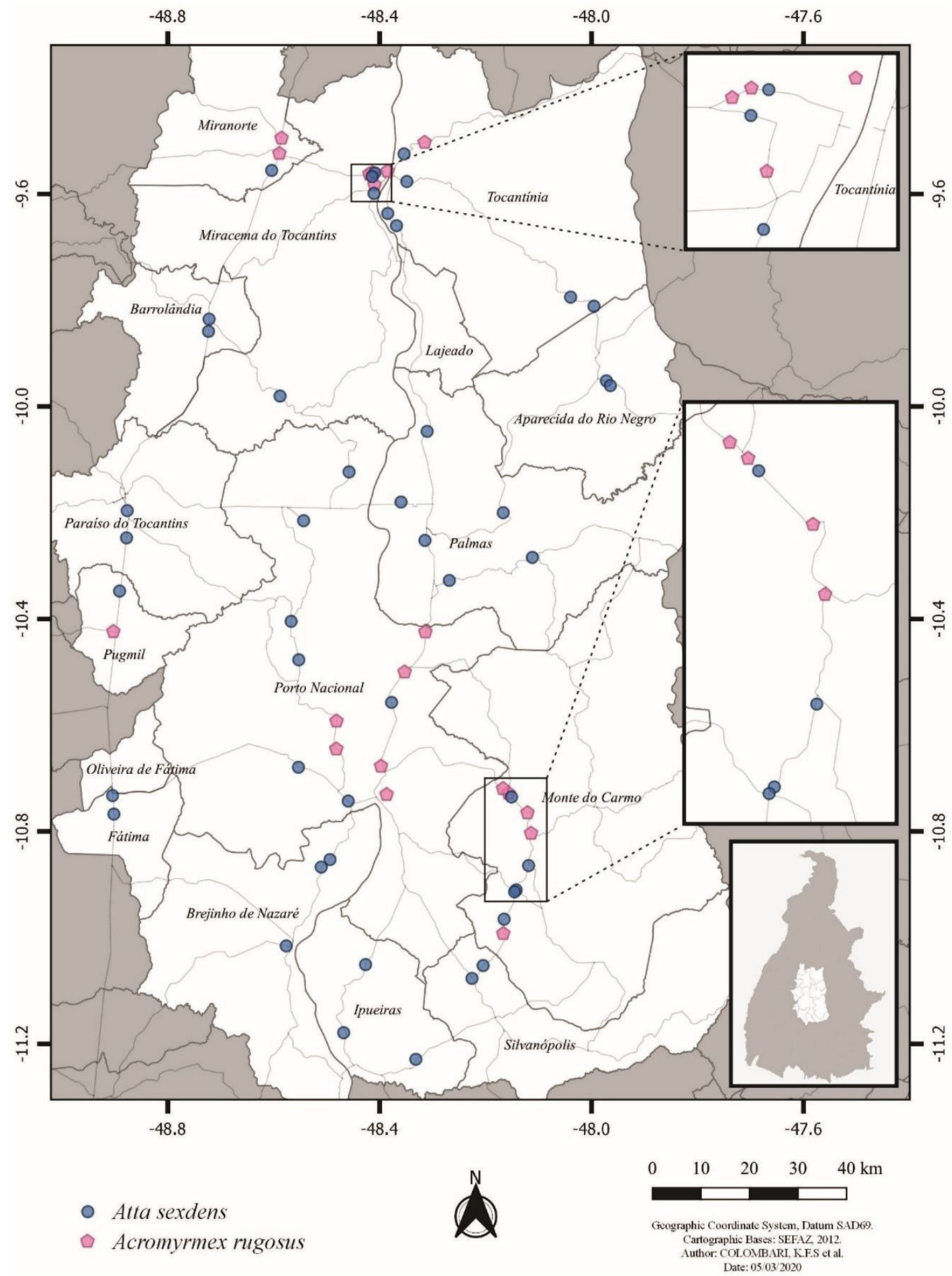

Figure 1. Distribution map of Atta sexdens and Acromyrmex rugosus in the central region of the state of Tocantins, Brazil. 
The five Acromyrmex species recorded in this study are known for their vast geographic distribution (see Forti and Boaretto, 1997; Silva Júnior et al., 2013). However, the low occurrence of Ac. coronatus in our survey may be related to its diversified form of nesting, which can occur on trees, on the ground surface, inside hollow wood, and on rural and

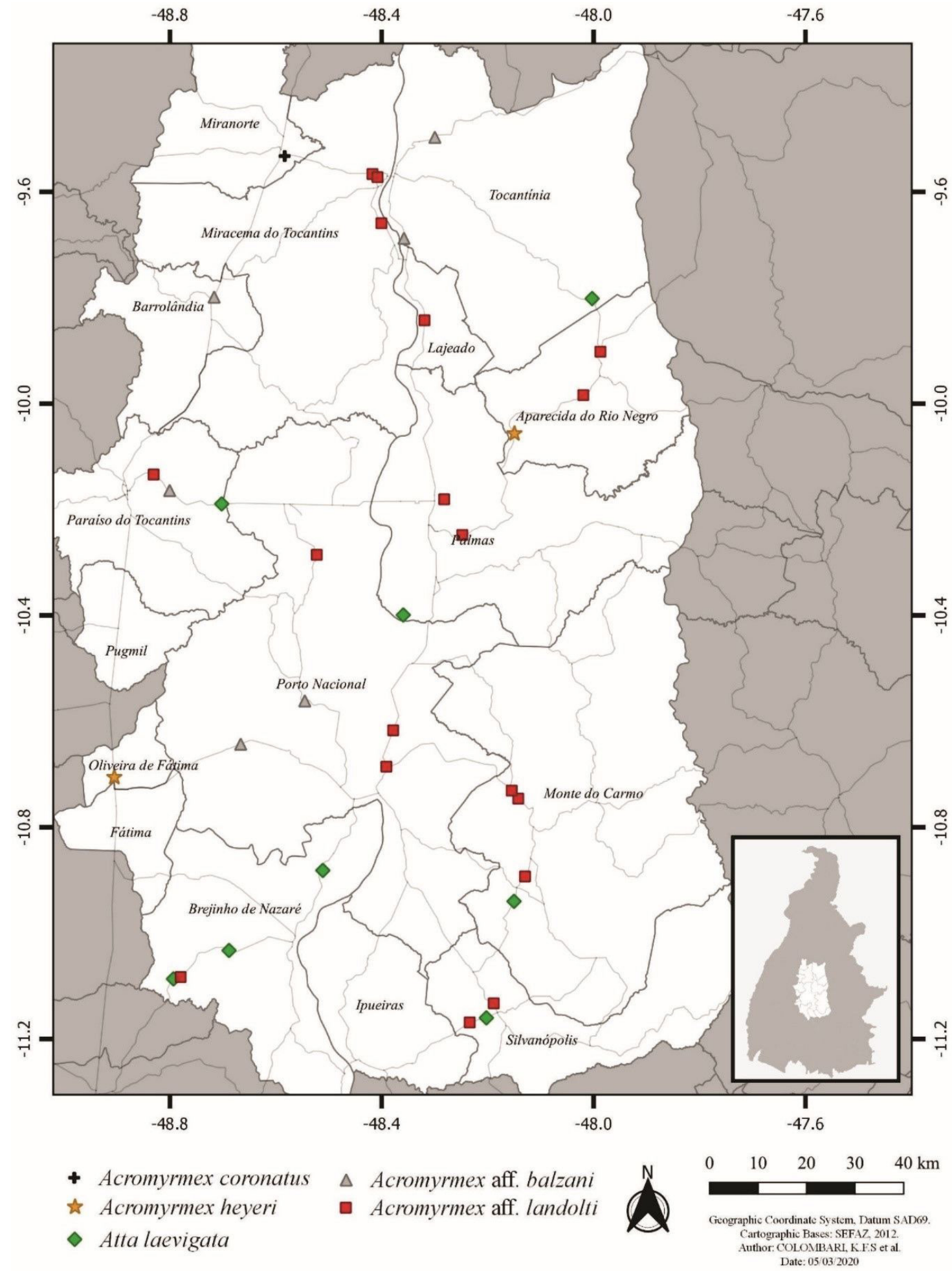

Figure 2. Distribution map of Acromyrmex coronatus, Acromyrmex heyeri, Atta laevigata, Acromyrmex aff. balzani and Acromyrmex aff. landolti in the central region of the state of Tocantins, Brazil. 
urban buildings (Forti et al., 2011). Acromyrmex balzani, Ac. heyeri, and Ac. landolti are specialized in grass cutting and known for the damages caused to pastures (Forti and Boaretto, 1997; Silva Júnior et al., 2013). Acromyrmex rugosus can be found in large areas planted with Eucalyptus, causing severe damage (Britto et al., 2016).

Although further research is necessary to ensure that the number of species is sufficiently represented (SouzaCampana et al., 2020), and to confirm the new record of Ac. aff. landolti, our pioneering survey of leaf-cutting ants in the state of Tocantins will be important for monitoring these populations, which need to be more sampled and studied, and will be able to contribute to decision-making for biodiversity conservation programs and integrated pest management.

\section{Acknowledgements}

We would like to acknowledge CNPq for the scholarship granted to the first author.

\section{References}

ANTWEB, 2021 [viewed 11 February 2021]. California Academy of Science [online]. Available from: https://www.antweb.org

ARRUDA, F., PESQUERO, M., PESQUERO, M. and SANTOS, J., 2020. Levantamento de espécies de formigas cortadeiras em vegetação nativa e monoculturas no estado de Goiás, Brasil. Boletim do Museu Paraense Emílio Goeldi. Ciências Naturais, vol. 15, no. 1, pp. 237-241. http://dx.doi.org/10.46357/bcnaturais.v15i1.237.

BOLTON, B., 2021 [viewed 11 February 2021]. An online catalog of the ants of the world [online]. Available from: https://antcat.org.

BRAGANÇA, M.A.L. and MEDEIROS, Z.C.S., 2006. Ocorrência e características biológicas de forídeos parasitóides (Diptera: Phoridae) da saúva Atta laevigata (Smith) (Hymenoptera: Formicidae) em Porto Nacional, TO. Neotropical Entomology, vol. 35, no. 3, pp. 408-411. http://dx.doi.org/10.1590/S1519566X2006000300018. PMid:18575704.

BRITTO, J.S., FORTI, L.C., OLIVEIRA, M.A., ZANETTI, R., WILCKEN, C.F., ZANUNCIO, J.C., LOECK, A.E., CALDATO, N., NAGAMOTO, N.S., LEMES, P.G. and CAMARGO, R.S., 2016. Use of alternatives to PFOS, its salts and PFOSF for the control of leafcutting ants Atta and Acromyrmex. International Journal of Research in Environmental Studies, vol. 3, pp. 11-92.

CHOE, J., 2012. Secret lives of ants. Baltimore: Johns Hopkins University Press, $184 \mathrm{p}$.

DÁTTILO, W., VICENTE, R.E., NUNES, R.V. and CARVALHO, M.S.G., 2010. Primeiro registro da quenquém cisco-da-Amazônia Acromyrmex hystrix Latreille (Formicidae: Myrmicinae) para o estado do Maranhão, Brasil. EntomoBrasilis, vol. 3, no. 3, pp. 92-93. http://dx.doi.org/10.12741/ebrasilis.v3i3.109.

DÁTTILO, W., VICENTE, R.E., NUNES, R.V. and FEITOSA, R.M., 2012. Influence of cave size and presence of bat guano on ant visitation. Sociobiology, vol.59, no. 2, pp. 549-559. http://dx.doi. org/10.13102/sociobiology.v59i2.617.

DELABIE, J.C.H., ALVES, H.S.R., REUSS-STRENZEL, G.M., CARMO, A.D. and NASCIMENTO, I.D., 2011. Distribuição das formigas cortadeiras Acromyrmex e Atta no Novo Mundo. In: T.M.C. DELLA-LUCIA, ed. Formigas-cortadeiras: da bioecologia ao manejo. Viçosa: UFV, pp. 80-101.
DORNELAS, A.S.P., SARMENTO, R.A., DOS SANTOS, G.R., NASCIMENTO, M.O. and DE SOUZA, D.J., 2016. Fungos filamentosos associados às espécies Atta sexdens (Linnaeus) e Atta laevigata (F. Smith) (Hymenoptera: formicidae). EntomoBrasilis, vol. 9, no. 1, pp. 26-30. http://dx.doi.org/10.12741/ebrasilis.v9i1.528.

FORTI, L.C. and BOARETTO, M.A.C., 1997. Formigas cortadeiras: biologia, ecologia, danos e controle. Botucatu: Universidade Estadual Paulista, $61 \mathrm{p}$.

FORTI, L.C., MOREIRA, A.A., ANDRADE, A.P., CASTELLANI, M.A. and CALDATO, N., 2011. Nidificação e arquitetura de ninhos de formigas-cortadeiras. In: T.M.C. DELLA LUCIA, ed. Formigascortadeiras: da bioecologia ao manejo. Viçosa: Ed. UFV, pp. 102-125.

FORTI, L.C., RANDO, J.S., CAMARGO, R.S., MOREIRA, A.A., CASTELLANI, M.A., LEITE, S.A., SOUSA, K.K.A. and CALDATO, N., 2020. Occurrence of leaf-cutting and grass-cutting ants of the genus Atta (Hymenoptera: Formicidae) in geographic regions of Brazil. Sociobiology, vol. 67, no. 4, pp. 514-525. http://dx.doi. org/10.13102/sociobiology.v67i4.5741.

FÓRUM NACIONAL DE ENTIDADES METROPOLITANAS - FNEM, 2019 [viewed 28 January 2021]. Região metropolitana de Palmas [online]. Available from: https://fnembrasil.org/regiaometropolitana-de-palmas-to/

FOWLER, H.G., DELLA-LUCIA, T.M.C. and MOREIRA, D.D.O., 1993. Posição taxonômica das formigas cortadeiras. In: T.M.C. DELLA LUCIA, ed. As formigas cortadeiras. Viçosa: Editora Folha de Viçosa, pp. 4-25.

GUÉNARD, B., WEISER, M., GOMEZ, K., NARULA, N. and ECONOMO, E.P., 2017. The Global Ant Biodiversity Informatics (GABI) database: a synthesis of ant species geographic distributions. Myrmecological News, vol. 24, pp. 83-89. http://dx.doi. org/10.25849/myrmecol.news_024:083.

JAIME, N.G., 2010. Levantamentos mirmecofaunísticos em três ambientes antrópicos nos Estados de Goiás e Tocantins, Brasil. Goiânia: Universidade Federal de Goiás, 131 p. Tese de Doutorado em Agronomia.

JORY, T.T. and FEITOSA, R.M., 2020. First survey of the ants (Hymenoptera, Formicidae) of Piauí: filling a major knowledge gap about ant diversity in Brazil. Papéis Avulsos de Zoologia, vol. 60, e20206014. http://dx.doi.org/10.11606/18070205/2020.60.14.

MARTINS, J., MOREIRA, A., ASSUNÇÃO, M., OLIVEIRA, A. and ALMEIDA, J., 2020. Trade-off in plant-ant interactions: seasonal variations. Brazilian Journal of Biology = Revista Brasileira de Biologia, vol. 80, no. 4, pp. 921-933. http://dx.doi. org/10.1590/1519-6984.229848. PMid:31967280.

MBENOUN MASSE, P.S.M., TINDO, M., KENNE, M., TADU, Z., MONY, R. and DJIETO-LORDON, C., 2017. Impact of the invasive ant Wasmannia auropunctata (Formicidae: Myrmicinae) on local ant diversity in southern Cameroon. African Journal of Ecology, vol. 55, no. 4, pp. 423-432. http://dx.doi.org/10.1111/aje.12366.

PRADO, L.P., FEITOSA, R.M., TRIANA, S.P., GUTIÉRREZ, J.A., ROUSSEAU, G.X., SILVA, R.A., SIQUEIRA, G.M., SANTOS, C.L., SILVA, F.V., SILVA, T.S.R., CASADEI-FERREIRA, A., SILVA, R.R. and ANDRADESILVA, J., 2019. An overview of the ant fauna (Hymenoptera: Formicidae) of the state of Maranhão, Brazil. Papéis Avulsos de Zoologia, vol. 59, e20195938. http://dx.doi.org/10.11606/18070205/2019.59.38.

SANTOS-SILVA, L., VICENTE, R.E. and FEITOSA, R.M., 2016. Ant species (Hymenoptera, Formicidae) of forest fragments and urban areas in a Meridional Amazonian landscape. Check List, vol. 12, no. 3, pp. 1885. http://dx.doi.org/10.15560/12.3.1885. 
SEBASTIANI, R., FUJIHARA, R.T. and GARCIA, M., 2017. Occurrence of ants (Hymenoptera: Formicidae) in Banisteriopsis laevifolia (A.Juss.) B.Gates (Malpighiaceae) in São Paulo State, Brazil. Brazilian Journal of Biology = Revista Brasileira de Biologia, vol. 77, no. 3, pp. 662-663. http://dx.doi.org/10.1590/1519-6984.03816. PMid:28099572.

SILVA JÚNIOR, M.R.S., CASTELLANI, M.A., MOREIRA, A.A., D'ESQUIVEL, M.S., FORTI, L.C. and LACAU, S., 2013. Spatial distribution and architecture of Acromyrmex landolti Forel (Hymenoptera, Formicidae) nests in pastures of Southwestern Bahia, Brazil Sociobiology, vol. 60, no. 1, pp. 20-29. http://dx.doi.org/10.13102/ sociobiology.v60i1.20-29.

SILVA, A. and SOUZA, D.J., 2014. Interação entre Atta sexdens e espécie arbórea Copaifera langsdorfii Desf. em remanescente florestal de Cerrado. Revista Verde de Agroecologia e Desenvolvimento Sustentável, vol. 9, no. 3, pp. 182-189.

SOUZA-CAMPANA, D.R., CARVALHO, A.C.N., CANALI, M., SILVA, O.G.M., MORINI, M.S.C. and FUJIHARA, R.T., 2020. A rapid survey of ground-dwelling ants (Hymenoptera: Formicidae) in an urban park from state of São Paulo, Brazil. Brazilian Journal of Biology $=$ Revista Brasileira de Biologia, vol. 80, no. 3, pp. 682-684 . http://dx.doi.org/10.1590/1519-6984.221831. PMid:31596363.

TORO, I.D., RIBBONS, R.R. and PELINI, S.L., 2012. The little things that run the world revisited: a review of ant-mediated ecosystem services and disservices (Hymenoptera: Formicidae). Myrmecological News, vol. 17, pp. 133-146.

VICENTE, R.E., FERREIRA, A.C., SANTOS, R.C.L. and PRADO, L.P., 2018. Ants (Hymenoptera: Formicidae) from an Amazonian fragmented landscape, Juara, Mato Grosso, Brazil, with new records of ant species. Papéis Avulsos de Zoologia, vol. 58, e20185840. http://dx.doi.org/10.11606/1807-0205/2018.58.40.

WILKIE, K.T.R., MERTL, A.L. and TRANIELLO, J.F., 2010. Species diversity and distribution patterns of the ants of Amazonian Ecuador. PLoS One, vol. 5, no. 10, pp. e13146. http://dx.doi. org/10.1371/journal.pone.0013146. PMid:20957208. 
Colombari, K.F.S. et al.

\section{Supplementary Material}

Supplementary material accompanies this paper.

Table 1. Leaf-cutting ants species collected in municipalities of the central region of the state of Tocantins, Brazil.

This material is available as part of the online article from http://www.scielo.br/bjb 